\title{
Determinants of Price Formation in Jember Regency, Indonesia
}

Adhitya Wardhono ${ }^{*}$

Yulia Indrawati ${ }^{1}$

Ciplis Gema Qori'ah1

Dwi Suslamanto²

\section{Doi:10.5901/mjss.2016.v7n4p}

\begin{abstract}
Price stability is a prerequisite in maintaining economic growth. Price stability or inflation in Indonesia has become the sole end target of the implementation of the monetary policy framework. However, the dynamic of inflation movement is predicted to result from the increase in commodity prices and domestic demand. This study aims to analyze the behavior of market participants in responding to information that potentially increases and lowers prices and the character of rationality owned by traders in Jember Regency. Based on the results of analysis of the condition of the occurrence of price changes, in general the cases of price increase or decrease are still dominated by the purchase price of the goods themselves. Meanwhile, the results of risk analysis of traders' preference showed that traders' response is asymmetric. Traders as the subjects tend to choose the option that gives certainty although it is harmful. The action and reaction between traders in the cases of price increase or decrease in one of the main commodities generate dominant strategies. The dominant strategies are taken when traders are in optimal conditions and react with each other.
\end{abstract}

Keywords: price stability, main strategies, determinants of price, market competition, competitiveness

\section{Introduction}

The dynamics of global economy that are increasingly rapid and integrated demand the importance of maintaining price stability (White, 2006). Price stability is a prerequisite in maintaining economic growth which is ultimately to achieve the improvement of social welfare (Gerdesmeier, Reimers, \& Roffia, 2009). Price stability or inflation in Indonesia has become the sole target at the end of the implementation of monetary policy framework, known as Inflation Targeting Framework (ITF) (Walsh, 2002). Bank Indonesia through a series of forward looking monetary policy is in effort of maintaining the price movement in line or approaching the inflation target as mandated in the ITF characteristics by considering various determinants or shock (Prijambodo, 2006). Theoretically, determinants and characteristics of inflation can be caused by demand, supply and also the expectations of economic agents referring to the Neo-Keynesian economic theory that Gordon (1997) calls as "The Triangle Model" (Laryea \& Sumaila, 2001; Gordon, 2009) .

Economic decisions made by households and corporations depend on the decision or the expectations on the future economic conditions; such behavior can be termed as adaptive inflation expectations (Capistr'an \& Timmermann, 2009). Other inflation expectations relate to price-wage spiral that can worsen the inflation expectations by forming a vicious circle of inflation, where inflation eventually pushes inflation itself to survive (Madeira \& Zafar, 2012). The negative impacts of the behavior of adaptive expectations and price-wage spiral towards the formation of built-in inflation can be reduced if economic agents' expectations come toward the forward-looking behavior by reference to the central bank inflation targets (Ravenna and Seppala, 2007).

The dynamics of the inflation movement, especially in the rising inflation of volatile food, have impacts on the core inflation (Bank Indonesia, 2013; Makinen \& Labonte, 2008). The stability of core inflation at $4 \%$ is supported by the easing of pressure from external factors such as prices of food and global gold as well as the relatively stable exchange rate. In the domestic scope, the subdued core inflation is also driven by adequate capability in the supply side in responding to the demand side development (Bernanke and Mishkin, 1997; Łyziak, 2014). In 2014, with a wide range of policies to control inflation, inflation is predictably controlled and within the inflation target range of $4.5 \%+1 \%$. In Jember Regency, 
the highest inflationary pressure occurred in the fourth-quarter of 2010, that is, $2.6 \%$ compared with the national inflation rate of $1.59 \%$. At the end of the first-quarter of 2013 , it was noticeably the highest at $2.8 \%$ with the moving national inflation at the level of $2.43 \%$. Thus, with regard to the importance of the characteristics of rationality of economic actors, it is really relevant that this study is to analyze more deeply about the characteristics of the determinants of inflation, in particular in Jember Regency, with some reviewing questions as follows:

1. How are the behaviors of market participants (the supply side), in this case consisting of traders of market and building supplies in response to a variety of information that potentially could lead to an increase or decrease in the price?

2. What type of information affected the behavior of traders of market and building supplies in raising or lowering prices?

3. How are rationality characteristics possessed by traders in Jember Regency?

\section{Review of Literature}

Modern economic theory views the fundamental differences between economics and natural sciences lying on forwardlooking decisions made by economic agents (Woodford, 2013; Ravenna and Seppala, 2007). Rational expectation (RE) assumes that the outcomes that will be predicted do not differ systematically from the market equilibrium (Mlambo, 2012; Tesfatsion, 2014). Meanwhile, the expected utility hypothesis is the theory of utility to get "preference betting" against the uncertain outcome or gambles indicated by payout function either in the form of money or other goods; this will likely to lead to risk aversion and different utility with the same payout and different assets or one's different option (Levin, 2006; Rabin, 1999). There are four axioms of the theory of expected utility theory which is defined as rational decisions i.e. completeness, transitivity, independence and continuity (Narahari, 2012).

Westcott \& Hoffman (1999) studied the determination of market prices for agricultural commodities in the United States. The study showed that the prices of agricultural products, especially corn and wheat, are determined by demand and supply in the country; more than that, prices are more dominantly determined by government policies and international standards of goods prices. Cornille \& Dossche (2006) use data Producer Price Index (PPI) to examine the determination of pricing in Industry of Belgium. The results of the study showed that one out of four prices can change within one month, while the absolute size of price changes is $6 \%$. In line with previous studies, Huang et al (2004) studied the determinants of price elasticity of goods with store brands and national brands. The study showed that the determinants of change in price increase and decrease are determined by the consumer interest and curiosity of the goods.

In Indonesia, the research by Hutabarat (2005) applying macro economy model SSMX (Small-Scale Macroeconomic Model Extended) during 1999 - 2004 reveals that the inflation is persistent and mostly influenced by the pattern of forming the expectation of inflation, such as previous inflation or adaptive expectation particularly supply shock such as oil prices shock, fuel price rise, devaluation and over fluctuation on currency rates and minimum wage rise. Consequently, several policies such as monetary policy, exchange rate policy, banking and government policy are importantly and necessarily integrated.

Lim and Papi (1997) conduct study on inflation determinant in Turkey for the period of 1970 to 1995 by applying Error Correction Model (ECM). The study indicates that the money supply and the exchange rate play the most important role to cause inflation amongst other factors such as inflation inertia and public sector deficit which affects inflation directly.

Pradiptyo et al. (2011) conduct study concerning the preference of factors or precise information for traders to determine price rise or price decrease toward local inflation reviewed from cost push and demand pull. Further, they also study real sector society's behaviour towards risky options. This study refers to that of Pradiptyo et al (2011) in viewing the inflation determinant from micro point of view, in which it considers market traders' response or perception towards price change. It differs from other researches in terms of their macro analysis on the determinants. The gaps between Pradipto et al (2011) is that this study applies strategy and response amongst the market traders if prices change occurs using game theory analysis and Analytical Hierarchy Process (AHP).

\section{Methodology}

\subsection{Types and Sources of Data}

Sources of data in this study consisted of primary data and secondary data. The primary data were obtained directly from 
the respondents i.e. traders of market and building supplies in Jember Regency. Selection of respondents was based on the consideration that the actors were pretty big contributors to price changes. The experiment involved 80 subjects of traders and businesspeople who were randomly selected. Meanwhile, the secondary data were obtained from publications/research reports from departments/agencies for supporting the data used in obtaining the description of inflation rate in Jember.

This research employs experiment method using market trader perception towards price change. The perception on price determinant is investigated using selective comparison for two factors either for price rise or for price decrease. There are 45 questions for investigating price rise, and 28 questions for price decrease respectively, thus overall questions are 73. For each questions, the participants have two option of factors and one option indicating choice for two similar important factors. To compare the two options, participants are asked to opt whether option A is more dominant than option B or vice versa, or both options $A$ and $B$ intensely influence their decision to increase or to decrease the prices.

Table 1. Indicators determinant for Price Increase and Decrease

\begin{tabular}{|c|l|l|}
\hline No. & Price Increase & Price Decrease \\
\hline 1. & Harvest Failure & Harvest Success \\
\hline 2. & Shortage supplies of goods & Abundant supplies of goods \\
\hline 3. & Disruption of goods distribution due to natural disasters & Decrease of the product's purchase price. \\
\hline 4. & Increased salary of Government Officials & Decreased prices done by competitors \\
\hline 5. & Increase in bank interest rates & Decrease in demand \\
\hline 6. & Increase of product purchase price & Decrease of fuel price \\
\hline 7. & Increased price done by competitors & Decrease of Electricity basic rates \\
\hline 8. & Increase of Demand & Decrease in Bank interest rates \\
\hline 9. & Increase of fuel price & \\
\hline 10. & Increase of electricity basic rates & \\
\hline
\end{tabular}

For each of experiment phase, the participants are required to determine for the price. At the last phase, the preference relation of participants can be identified and tie break are found in the preference. For one particular questions, several participants will indicate $A>B$, however, surely others will claim that $A<B$, or even $A \sim B$. The $A \sim B$ option is a tie break condition which is considered as neutral with zero scoring, either for factor $A$ or factor $B$ and vice versa. If this applies to all questions related to factors influencing price rise, therefore, the result would be the participants' preference towards factors determining the price. At this phase, tie break is still possible to occur, that is when the number of participants indicating $\mathrm{A}>\mathrm{B}$ is more than those asserting $\mathrm{A}<\mathrm{B}$. when tie break take place, it would be assumed that the two factors are of the same level of preference.

\subsection{Data Analysis Methods}

Methods of analysis used to empirically answer the first, second, and third questions consisted of three methods of analysis. First, Expected Utility Theory method, second, Analytic Hierarchy Process (AHP) method, and third, Game Theory method.

\subsubsection{Expected Utility Theory}

To determine the characteristics of traders' or businesspeople's rationality in risky option, Expected Utility Theory is a model that explains the decision analysis based on risks. This theory becomes a normative model of a rational choice. This model has been widely used as a descriptive model of economic behavior (Rabin, 1999). Von Neuman and Morgenstern mention the implications of expected utility theory in selecting a prospect based on three principles, namely (Narahari, 2014):

1. Expectation: $U(x 1, p 1 ; \ldots ; x n,, p n)=p 1 u(x 1)+\ldots+p n u(x n)$. An expectation of utility is the number of possible utility outcomes, $x i$, multiplied by the coming possibility of the utility, $u(x i)$

2. Asset Integration: $(x 1, p 1 ; \ldots ; x n, p n)$ can be received at a position of wealth $w$, if $U(w+x 1, p 1 ; \ldots ; w+x n$, $\mathrm{pn})>\mathrm{u}(\mathrm{w})$. Someone will receive a prospect if the prospect brings more benefits than that if he does not receive it. 
3. Risk aversion: $u$ has concave, $\left(u^{\prime \prime}<0\right)$. Someone's preference will decline when facing the prospect of higher risk.

\subsubsection{Analytic Hierarchy Process (AHP)}

AHP is a decision-making method using the main equipment, that is, a hierarchy, where a complex and unstructured problem is solved, grouped and organized into a hierarchical form. Saaty (2008) explains that AHP has a particular concern about the deviation of consistency, so that AHP is widely found in decision-making for many criteria, planning, forecasting, and resource allocation. The stages in the data analysis are as follows (Saaty, 2008): (1) system identification. (2) preparation of hierarchical structure, (3) paired comparison, (4) matrix of composite opinion, (5) horizontal processing, (6) vertical processing.

\subsubsection{Game Theory}

Game theory is a mathematical model that is used in situations of conflict or competition between various interests that face each other as competitors (Narahari, 2012; Harbaugh et al, 2007). In this game, participants are competitors. The advantage for one is a loss for the other(s). There are two kinds of two person zero sum games; first, pure strategy game and, second, mixed strategy game (Turocy \& Stengel, 2001).

\section{Results and Discussion}

\subsection{Key determinants of Price Formation and Change}

Commodity price formation in traditional markets is more dominantly determined by the distributor price of $58.8 \%$, cost of goods sold (COGS) of $35 \%$ and marketing cost of $6.2 \%$. Changes in prices can be influenced by the volume of goods stock at the distributor level, especially at the level of traders and wholesalers. Meanwhile, the determination of the selling price of goods is mostly influenced by the pure price calculated from the direct costs and the gained margin of $68.8 \%$, determined by the parent company at $18.8 \%$, following the major competitors only at $5 \%$, and the price is determined by the highest level that is acceptable to market at $5 \%$ and others at $2.4 \%$.

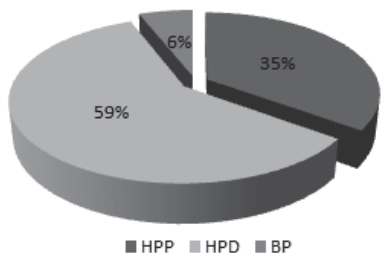

Figure 1. Determinants of Price Formation

Figure 2. Intensity of Price Changes

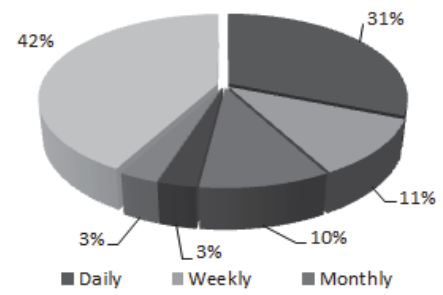

Figure 2 below describes that price changes are frequent caused by various factors both short term and long term. Changes in macro-economic dynamics of and other external disturbances such as supply disruptions caused by disasters, the increase in world crude oil prices or other disturbances can affect the changes in market prices. Based on survey, according to the respondents, intensity of price changes occurred almost every day $31.3 \%$, weekly $11.3 \%$, 
monthly $10 \%$, yearly $2.5 \%$, never $2.5 \%$ and others $42.4 \%$ more concentrated in particular months such as before Eid, Christmas and short term surprises which were not anticipated.

\subsubsection{Subject Preference toward Determinants of Price Increase}

Some determinants of price increase conveyed in 45 questions asked to subjects showed traders' preference in increasing the price of the goods or products sold as seen in table 2 below:

Table 2. Ranks of Determinants of Price Increase

\begin{tabular}{|c|l|c|c|}
\hline No. & Determinants of Price Increase & Dominance toward other factors & Rank \\
\hline 1. & Increase in purchase price of Products & 8 & 2 \\
\hline 2. & Increase in fuel price & 7 & 3 \\
\hline 3. & Harvest failure & 7 & 3 \\
\hline 4. & Scarcity of goods & 7 & 3 \\
\hline 5. & Increase in demand & 5 & 5 \\
\hline 6. & Troubles in goods distribution due natural disasters & 4 & 6 \\
\hline 7. & Price raising by competitors & 3 & 7 \\
\hline 8. & Increase in basic electricity tariff & 2 & 8 \\
\hline 9. & Increse in bank interest rate & 2 & 8 \\
\hline 10. & Increase in government employee salary & 0 & 10 \\
\hline
\end{tabular}

Source: Primary data, processed, 2013

Table 2 shows the traders' preference toward the factors that affected the behavior of increasing the price of goods sold. The first rank is the increase in the purchase price of products. The selling price of goods by traders was strongly influenced by the purchase price at distributor level. If the distributors tended to raise prices, then automatically prices at the trader level would also experience an increase as the compensation of closing the rise in prices at distributor level. Meanwhile, the second rank is the increase in fuel prices which was cost push inflation, as input prices tended to rise and wpuld increase the production cost which ultimately would increase the price of output. The third rank is the failure of the harvest which is the most influential factor for traders in increasing prices caused by disturbances on the supply side in which the harvests failure reduced the supply of basic goods, especially volatile foods such as foodstuffs, vegetables and fruits.

\subsubsection{Subject Preference toward Determinants of Prices Decrease}

Some determinants of price decrease conveyed in 28 questions asked to subjects showed traders' preference in decreasing the prices of goods or products sold as seen in Table 3. Table 3 shows the preference of sellers on the factors that influenced the behavior of lowering the price of goods sold is more dominantly influenced by the decline in the purchase price of goods. This rank is the same as the rank of the main factors of the price increase. The selling price of goods by sellers is strongly influenced by the purchase price at the distributor level. The third ranked factor is the factor of competitor in lowering the price of products.

Table 3. Determinants of Price Decline

\begin{tabular}{|c|l|c|c|}
\hline No. & Determinants of Price Increase & Dominance toward other factors & Rank \\
\hline 1. & Decline in product purchase price & 6 & 2 \\
\hline 2. & Smoothness of goods supply & 5 & 3 \\
\hline 3. & Price reduction by competitors & 4 & 3 \\
\hline 4. & Harvest success & 4 & 4 \\
\hline 5. & Decrease in Demand & 2 & 4 \\
\hline 6. & Decrease in fuel price & 1 & 6 \\
\hline 7. & Decrease in bank interest rate & 0 & 7 \\
\hline 8. & Decrease in basic electricity tariff & & 8 \\
\hline
\end{tabular}

Source: Primary data, processed, 2013 
In reality, the competitive situation in the market is the factor that cannot be avoided. This is because the conditions of high competition among sellers in lowering prices will affect consumers' interests, especially those with a high sensitivity to price. Thus, lowering the price determined by competitors will be responded quickly by the subject of traders in maintaining the continuity of the goods sales.

\subsubsection{Subject of Traders Preference toward Risks}

The next stage of the experiment on the subject of traditional traders in Jember was measuring the subjects' behavior toward the prospect of risks. A prospect is said to be at risk if the probability of a prospect is identified. This stage consisted of six sections which indicated the failure of Utiity Expected Theory in explaining the behavior of the subject of traders.

\subsubsection{Part l: Testing misalignment Preferences}

Stages in the testing of subjects' preference unconformity are applicable to questions 1 to 6 in simulation technique. Data resulted from the simulation showed that 37 of 40 subjects traders chose option $B$, and 3 of 40 subjects chose $A$ in Question 1. This showed that $U(80,000)>(0.33) \cdot U(100,000)+(0.66) \cdot U(80,000)$ assuming that $U(0)=0$. Here are the answers to question no. 1 to choose one of two

Number 1

\begin{tabular}{|c|c|c|c|}
\hline \multicolumn{4}{|c|}{ Number 1.} \\
\hline A: & $\begin{array}{l}\text { IDR } 100,000,- \text { probability } 33 \% \\
\text { IDR } 80,000,- \text { probability } 66 \%\end{array}$ & B : & IDR 80,000 ,- probability $100 \%$ \\
\hline $\mathrm{N}=40$ & $7,5 \%$ & & $92,5 \%$ \\
\hline
\end{tabular}

Meanwhile, question number 2 reduced the possibility of the acquisition value of IDR 80,000 .- by 0.66 for either option $A$ or option B. The experimental results showed that 17 subjects chose $A$ and 23 subjects chose $B$. This showed that there was no violation of the expected utility theory as stated by Allais (1953), where the utility expectation is the number of expected utility of the number of probability utility multiplied by the utility probability.

Number 2

\begin{tabular}{|lccc|}
\hline Number 2. & & \\
A : & IDR $100,000,-$ probability $33 \%$ & B : & IDR. 80,000, - probability $34 \%$ \\
$\mathrm{~N}=40$ & $42,5 \%$ & & $57,5 \%$ \\
\hline
\end{tabular}

Question number 3 is a modification of question 1 by reducing the possibility of purchase of IDR 80,000 .- by 0.33 , on both option A and B. The experiment results showed that four subjects chose $A$ and 36 subjects chose $B$. This pattern did not show any violation of expected utility theory where this theory emphasizes that changes in the probability of options $A$ and $B$ will not change the preferences of the individual in making risky decisions.

Number 3

\begin{tabular}{|lrlc|}
\hline \multicolumn{2}{|c|}{ Number 3.} & & \\
A : & $\begin{array}{l}\text { IDR. } 100,000 \text {,- probability } 33 \% \\
\text { IDR. } 80,000, \text { - probability } 33 \%\end{array}$ & B : & IDR. 80,000 ,- probability $67 \%$ \\
$N=40$ & $10 \%$ & & $90 \%$ \\
\hline
\end{tabular}

The experimental results for numbers 1 to 3 indicated that sellers tended to choose more on the prospects that provided a more definite possiblity of outcome. Meanwhile, questions 4, 5, and 6 were also a modification of questions 1, 2 and 3 by changing the pay off value of IDR 100,000.- to IDR 50,000.-. The experimental data showed that the subject of traders 
still chose the prospect with more definite possibility of outcome i.e. option B had more than option A

Numbers $4,5,6$

\begin{tabular}{|lcc|}
\hline Number 4. & & \\
A : & IDR. 50,000, - probability $33 \%$ \\
IDR. 40,000, - probability $66 \%$ & B : & IDR. 40,000 ,- probability $100 \%$ \\
$\mathrm{~N}=40$ & $7,5 \%$ & $92,5 \%$ \\
\hline
\end{tabular}

\begin{tabular}{|lccc|}
\hline \multicolumn{2}{|l|}{ Number 5. } & & \\
A : & IDR. 50.000 ,- probability $33 \%$ \\
IDR. $40.000,-$ probability $33 \%$ & B : & IDR. 40.000 ,- probability $67 \%$ \\
$\mathrm{~N}=40$ & $5 \%$ & & $95 \%$ \\
\hline
\end{tabular}

\section{Number 6.}

\begin{tabular}{|c|c|c|c|}
\hline A : & IDR. 50.000 ,- probability $33 \%$ & B : & IDR. 40.000 ,- probability $34 \%$ \\
\hline $\mathrm{N}=40$ & $40 \%$ & & $60 \%$ \\
\hline
\end{tabular}

Questions 7, 8 and 9 are a modification of questions number 4.5 and 6 where the pay off value was converted into the loss value of IDR 50,000.-and IDR 40,000. The experimental results showed that option A was greater than option B. This is in line with the results of experiments on numbers 4,5 and 6 in which the subjects remained to select prospects with more definite possibility of value.

Numbers $7,8,9$

\begin{tabular}{|c|c|c|c|}
\hline \multicolumn{4}{|c|}{ Number 7.} \\
\hline A : & $\begin{array}{l}\text { (IDR. } 50.000,-) \text { probability } 33 \% \\
\text { (IDR. } 40.000,- \text { ) probability } 66 \%\end{array}$ & B : & (IDR. $40.000,-$ ) probability $100 \%$ \\
\hline $\mathrm{N}=40$ & $62,5 \%$ & & $37,5 \%$ \\
\hline \multicolumn{4}{|c|}{ Number 8.} \\
\hline A: & $\begin{array}{l}\text { (IDR. } 50.000 \text {,-) probability } 33 \% \\
\text { (IDR. } 40.000 \text {,-) probability } 33 \%\end{array}$ & B : & (IDR. $40.000,-$ ) probability $67 \%$ \\
\hline $\mathrm{N}=40$ & $62,5 \%$ & & $37,5 \%$ \\
\hline \multicolumn{4}{|c|}{ Number 9.} \\
\hline A : & (IDR.50.000,-) probability $33 \%$ & B : & (IDR. $40.000,-$ ) probability $34 \%$ \\
\hline $\mathrm{N}=40$ & $62,5 \%$ & & $37,5 \%$ \\
\hline
\end{tabular}

\subsubsection{Part II: Testing of Preference Mismatch}

The second part is the testing of the presence of violation of the substitution axiom, in which subjects tended to choose the option that provided certainty on the pay off value. Question number 10 shows that 29 subjects chose option B. This gives preference that:

$$
(0.80) \cdot U(100,000)<((1.00) \cdot U(70,000)
$$




\section{Number 10}

\begin{tabular}{|lcc|}
\hline $\begin{array}{l}\text { Number } 10 . \\
\text { A : } \quad \text { IDR. } 100.000 \text {,- probability } 80 \%\end{array}$ & B : & IDR. 70.000 ,- probability $100 \%$ \\
$\mathrm{~N}=40$ & $27,5 \%$ & $72,5 \%$ \\
\hline
\end{tabular}

Question number 11 is a modification of question number 10 by multiplying the probability of option A and option B with 0.25 and the experimental results still showed option $B$. This gives preference that:

$(0.25) \cdot(0.80) \cdot U(100,000)<(0.25) \cdot(1 \cdot 00) \cdot U(70,000)$

\section{Number 11}

\begin{tabular}{|c|c|c|c|}
\hline \multicolumn{4}{|c|}{ Number 11.} \\
\hline A: & IDR. 100.000 ,- probability $20 \%$ & B : & IDR. 70.000 ,- probability $25 \%$ \\
\hline $\mathrm{N}=40$ & $37,5 \%$ & & $62,5 \%$ \\
\hline
\end{tabular}

According to expected utility theory, subjects will choose option A for number 10 and still choose A for number 11 . However, as many as 29 subjects chose B for number 10 and 25 subjects chose B for number 11 . The subjects tended to choose the option that gave certainty $(p=1.00)$ to the pay off value or called certainty effect.

\begin{tabular}{|c|c|c|c|}
\hline \multicolumn{4}{|c|}{ Number 12.} \\
\hline A: & IDR. 100.000 ,- probability $40 \%$ & B : & IDR. 70.000 ,-probability $50 \%$ \\
\hline$N=40$ & $32,5 \%$ & & $67,5 \%$ \\
\hline \multicolumn{4}{|c|}{ Number 13.} \\
\hline A: & IDR. 50.000 ,- probability $80 \%$ & B : & IDR. 30.000 ,- probability $100 \%$ \\
\hline $\mathrm{N}=40$ & $30 \%$ & & $70 \%$ \\
\hline \multicolumn{4}{|c|}{ Number 14.} \\
\hline A: & IDR. 100.000 ,- probability $20 \%$ & B : & IDR. 30.000 ,-probability $25 \%$ \\
\hline$N=40$ & $42,5 \%$ & & $57,5 \%$ \\
\hline \multicolumn{4}{|c|}{ Number 15.} \\
\hline A : & IDR. 50.000 ,- probability $40 \%$ & B : & IDR. 30.000 ,-probability $50 \%$ \\
\hline $\mathrm{N}=40$ & $37,5 \%$ & & $62,5 \%$ \\
\hline
\end{tabular}

Questions 10 to 15 suggest that the subjects tended to choose the option that gave certainty to the pay off value. Meanwhile, the subjects also remained to choose the options that provided greater certainty when the two options did not provide probability of 1 . These findings support the hypothesis of certainty effect stated by Kahneman and Tversky (1979). Questions 16 to 18 are a modification of questions 13 to 15, in the case of loss value, in which subjects would choose option A that gave the small probability of loss. 
Numbers 16, 17, 18

\begin{tabular}{|c|c|c|c|}
\hline \multicolumn{4}{|c|}{ Number 16.} \\
\hline A : & (IDR. $50.000,-$ ) probability $80 \%$ & B : & (IDR. $30.000,-$ ) probability $100 \%$ \\
\hline $\mathrm{N}=40$ & $52,5 \%$ & & $47,5 \%$ \\
\hline \multicolumn{4}{|c|}{ Number 17.} \\
\hline A : & (IDR. $50.000,-$ ) probability $20 \%$ & B : & (IDR. 30.000 ,-) probability $25 \%$ \\
\hline$N=40$ & $62,5 \%$ & & $37,5 \%$ \\
\hline \multicolumn{4}{|c|}{ Number 18.} \\
\hline A : & (IDR. 50.000 ,-) probability $40 \%$ & B: & (IDR. $30.000,-$ ) probability $50 \%$ \\
\hline $\mathrm{N}=40$ & $60 \%$ & & $40 \%$ \\
\hline
\end{tabular}

\subsubsection{Part III: Testing of Subject Preference Relative to Probability Pertubation}

The third part is the testing of subject preference relative to probability pertubation. Questions 19 to 24 subjects showed subject tendency to choose options that provided a greater probability of a pay off.

Numbers $19,20,21,22,23,24$

\begin{tabular}{|c|c|c|c|}
\hline \multicolumn{4}{|c|}{ Number 19.} \\
\hline A: & IDR. 100.000 ,- probability $45 \%$ & B : & IDR. 50.000 ,- probability $90 \%$ \\
\hline $\mathrm{N}=40$ & $25 \%$ & & $75 \%$ \\
\hline \multicolumn{4}{|c|}{ Number 20.} \\
\hline A: & IDR. 100.000 ,- probability $1 \%$ & B : & IDR. 50.000 ,-probability $2 \%$ \\
\hline $\mathrm{N}=40$ & $32,5 \%$ & & $67,5 \%$ \\
\hline \multicolumn{4}{|c|}{ Number 21.} \\
\hline A : & IDR. 100.000 ,- probability $2 \%$ & B : & IDR. 50.000 ,- probability $4 \%$ \\
\hline $\mathrm{N}=40$ & $35 \%$ & & $65 \%$ \\
\hline \multicolumn{4}{|c|}{ Number 22.} \\
\hline A: & IDR. 50.000 ,- probability $45 \%$ & B : & IDR. 25.000 ,- probability $90 \%$ \\
\hline $\mathrm{N}=40$ & $12,5 \%$ & & $87,5 \%$ \\
\hline \multicolumn{4}{|c|}{ Number 23.} \\
\hline A : & IDR. 50.000 ,- probability $1 \%$ & B : & IDR. 25.000 ,- probability $2 \%$ \\
\hline $\mathrm{N}=40$ & $42,5 \%$ & & $57,5 \%$ \\
\hline \multicolumn{4}{|c|}{ Number 24.} \\
\hline A : & IDR. 50.000 ,- probability $50 \%$ & B : & IDR. 50.000 ,-probability $100 \%$ \\
\hline $\mathrm{N}=40$ & $10 \%$ & & $90 \%$ \\
\hline
\end{tabular}




\subsubsection{Part IV: Testing of Loss Aversion Hypothesis}

This part is loss aversion hypothesis testing, where the utility is not based on the final position of wealth, but rather its changes. This experiment observed hypothesis about the behavior of loss aversion on the subjects. Question 25 showed that subjects faced option A, that is, 0.50 paying IDR 50,000.- or B paying IDR 25,000.-. The experimental results showed that 21 subjects chose option A compared to $B$. Meanwhile, question number 26 showed that the subject faced the option A, that is, 0.50 gaining IDR 100,000.- and 0.50 gaining IDR 50,000.-while option B is to gain exactly IDR 75,000.- The experimental results showed that 33 subjects chose $B$. Thus, in this case, the subject behaved loss aversion in making a decision.

\begin{tabular}{|c|c|c|c|}
\hline \multicolumn{4}{|c|}{ Numbers 25, 26, 27} \\
\hline \multicolumn{4}{|c|}{ Number 25.} \\
\hline A: & (IDR.50.000,-) probability $50 \%$ & B : & (IDR. 25.000 ,-) probability $100 \%$ \\
\hline $\mathrm{N}=40$ & $52,5 \%$ & & $47,5 \%$ \\
\hline \multicolumn{4}{|c|}{ Number 26.} \\
\hline A : & $\begin{array}{l}\text { IDR. } 100.000 \text {,- probability } 50 \% \\
\text { IDR. } 50.000 \text {-- probability } 50 \%\end{array}$ & B : & IDR. 75.000 ,- probability $100 \%$ \\
\hline $\mathrm{N}=40$ & $17.5 \%$ & & $82.5 \%$ \\
\hline \multicolumn{4}{|c|}{ Number 27.} \\
\hline A: & IDR. 40.000 ,- probability $25 \%$ & B : & IDR. 10.000 ,- probability $100 \%$ \\
\hline $\mathrm{N}=40$ & $15 \%$ & & $85 \%$ \\
\hline
\end{tabular}

\subsubsection{Part V: Testing of Preference Consistency toward Pay Off Value Pertubation}

The fifth part is the series to see the consistency of subject preference toward pertubation of pay off value. Questions 28 to 36 are questions to test the preference consistency. Most respondents chose $B$ rather than $A$. This indicates that the pertubation value does not affect the value of subject preference. The subjects chose the option with the definite probability of pay off. Thus, in this case, the utility function does not turn into a convex on adverse option and these results are in contrast with those of Kahneman and Tversky (1979) and Markowitz (1952).

Number 28, 29, 30, 31, 32, 33, 34, 35, 36

\begin{tabular}{|c|c|c|c|}
\hline \multicolumn{4}{|c|}{ Number 28.} \\
\hline A: & (IDR.40.000,-) probability $25 \%$ & B : & (IDR. $10.000,-$ ) probability $100 \%$ \\
\hline $\mathrm{N}=40$ & $42,5 \%$ & & $57,5 \%$ \\
\hline \multicolumn{4}{|c|}{ Number 29.} \\
\hline A: & IDR. 10.000 ,- probability $25 \%$ & B : & IDR. 2.500 ,- probability $100 \%$ \\
\hline $\mathrm{N}=40$ & $27,5 \%$ & & $72,5 \%$ \\
\hline \multicolumn{4}{|c|}{ Number 30.} \\
\hline A: & (IDR.10.000,-) probability $25 \%$ & B : & (IDR. $2.500,-$ ) probability $100 \%$ \\
\hline $\mathrm{N}=40$ & $35 \%$ & & $65 \%$ \\
\hline \multicolumn{4}{|c|}{ Number 31.} \\
\hline A: & IDR. 20.000 ,- probability $25 \%$ & B : & IDR. 5.000 ,- probability $100 \%$ \\
\hline $\mathrm{N}=40$ & $25 \%$ & & $75 \%$ \\
\hline
\end{tabular}




\begin{tabular}{|c|c|c|c|}
\hline \multicolumn{4}{|c|}{ Number 32 . } \\
\hline A : & (IDR.20.000,-) probability $25 \%$ & B : & (IDR. $5.000,-$ ) probability $100 \%$ \\
\hline$N=40$ & $40 \%$ & & $60 \%$ \\
\hline \multicolumn{4}{|c|}{ Number 33.} \\
\hline A: & IDR. 30.000 ,- probability $25 \%$ & B : & IDR. 7.500 ,- probability $100 \%$ \\
\hline $\mathrm{N}=40$ & $17,5 \%$ & & $82,5 \%$ \\
\hline \multicolumn{4}{|c|}{ Number 34 . } \\
\hline A: & (IDR. $30.000,-$ ) probability $25 \%$ & B : & (IDR. $7.500,-$ ) probability $100 \%$ \\
\hline $\mathrm{N}=40$ & $47,5 \%$ & & $52,5 \%$ \\
\hline \multicolumn{4}{|c|}{ Number 35 . } \\
\hline A : & IDR. 50.000 ,- probability $25 \%$ & B : & IDR. 12.500 ,-probability $100 \%$ \\
\hline $\mathrm{N}=40$ & $20 \%$ & & $80 \%$ \\
\hline \multicolumn{4}{|c|}{ Number 36 . } \\
\hline A: & (IDR. $50.000,-$ ) probability $25 \%$ & B : & (IDR. $12.500,-$ ) probability $100 \%$ \\
\hline $\mathrm{N}=40$ & $40 \%$ & & $60 \%$ \\
\hline
\end{tabular}

\subsubsection{Part VI: Testing of Subject Preference to small probability}

The last part of this experiment sees the subject preference in a very small probability. Questions 37 to 41 suggest that most of the subjects tended to behave a risk averse when facing an option. Most subjects chose $B$ compared to $A$ in which option A provided a probability by $1(p=1.00)$. This is consistent with previous experimental results which chose the more definite probability of pay off.

Numbers $37,38,39,40,41$

\begin{tabular}{|c|c|c|c|}
\hline \multicolumn{4}{|c|}{ Number 37 . } \\
\hline A: & IDR. 100.000 ,- probability $1 \%$ & B : & IDR. 1.000 ,- probability $100 \%$ \\
\hline $\mathrm{N}=40$ & $30 \%$ & & $70 \%$ \\
\hline \multicolumn{4}{|c|}{ Number 38.} \\
\hline A: & IDR. 50.000 ,- probability $1 \%$ & B : & IDR. 500 ,- probability $100 \%$ \\
\hline $\mathrm{N}=40$ & $40 \%$ & & $60 \%$ \\
\hline \multicolumn{4}{|c|}{ Number 39.} \\
\hline A : & (IDR.50.000,-) probability $1 \%$ & B : & (IDR. $500,-$ ) probability $100 \%$ \\
\hline $\mathrm{N}=40$ & $27,5 \%$ & & $72,5 \%$ \\
\hline \multicolumn{4}{|c|}{ Number 40.} \\
\hline A : & IDR. 50.000 ,- probability $2 \%$ & B : & IDR. 1.000 ,- probability $100 \%$ \\
\hline $\mathrm{N}=40$ & $37,5 \%$ & & $62,5 \%$ \\
\hline \multicolumn{4}{|c|}{ Number 41.} \\
\hline A : & (IDR. $50.000,-$ ) probability $2 \%$ & B : & (IDR. 1.000 ,-) probability $100 \%$ \\
\hline $\mathrm{N}=40$ & $32,5 \%$ & & $67,5 \%$ \\
\hline
\end{tabular}




\subsubsection{The Relationship between Preference of of Factors of Price Change and Risk}

Discussion of the preference of factors of price changes concludes that the sellers' response is asymmetric. The difference in response is closely related to the subject preferences to risks. Ideally, the reflection effect is a logical consequence of the individual behavior which is loss aversion. In beneficial conditions, the individual will behave in risk aversion. However, in adverse conditions, people will be risk seekers. Respondents tend to choose an option that gives certainty although it is harmful. This illustrates that the anticipation of respondents to the risk is also not symmetric. Asymmetric response to risk is a reflection of what subjects expected in facing the uncertainty of a prospect.

\subsection{Behavioral Response between Subjects of Sellers to Price Change: the Case of Price Increase}

In the case of increase in price, here is an interaction model and strategy of subjects of sellers dealing with the increase in price.

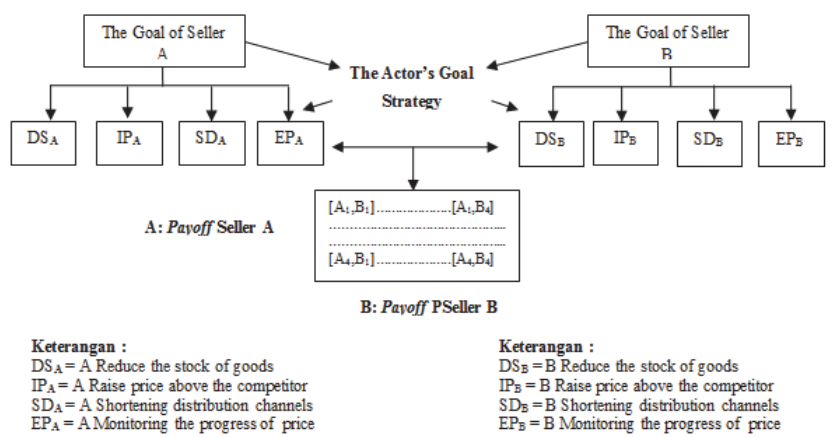

Figure 3. Strategies and Responses between subjects toward Price Increase

Figure 3 shows responses to each of sellers $A$ and $B$ toward the condition of the price increase. The strategies made by sellers $A$ and $B$ are reducing the amount of goods, raising the prices above the market or the main competitor prices, shortening the distribution of goods to suppress the purchase price and monitoring the progress of goods price. Interaction between sellers A and B occur at any strategy made by either A or B. Then, the payoff of both sellers A and B will be calculated as a consequence of the interaction between the strategies of $A(B)$ vis a vis the alternative strategies of $B(A)$. Consequence of payoff is determined by AHP technique and arranged within the framework of game theory. Here is a behavioral response among subjects of sellers to price changes in one of the commodities in Jember Regency.

\subsubsection{Commodity Rice}

Fluctuation in the price of rice as the most important basic need for the people in Indonesia is one of the inflation contributors. High dependency of Indonesian people on this commodity may cause vulnerability to fluctuations in the price of rice and the prices of goods in general. Here is the calculation of strategic priorities of subject of seller $A(B)$ with respect to the goal of seller $A(B)$ and in relation to each of the subject strategy of seller $B(A)$. The weight or priority vectors of each strategy of seller $A$ is in relation to the B's goal.

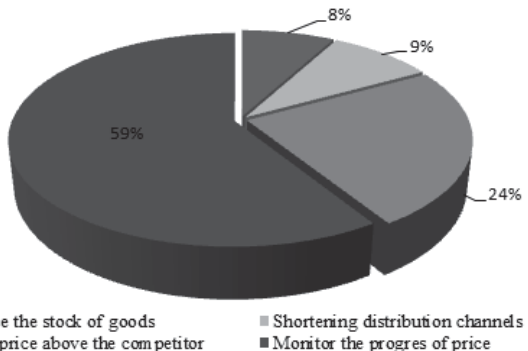

Figure 4. Priorities and Strategies of Subject of Seller A with respect to the goal

Description: Consistency Index of 0.06, Source: Primary data, processed, 2013 
In figure 4 , the priority strategies made by seller A are monitoring the price development with a weight of 0.592 and followed by a strategy to raise the price above the market and the main competitor prices with a weight of 0.241 . Any strategy made seller $A$ is faced with any strategy of subject of seller B. Accordingly, every action in strategy $B$, there is strategy $A$ which is the most effective to respond to action $B$. The reactions of subject of seller $A$ to any strategy made seller $\mathrm{B}$ are as follows:

Table 4. Priority Strategy of Seller A with respect to Strategy of Seller B

\begin{tabular}{|c|c|c|c|c|c|}
\hline & \multicolumn{4}{|c|}{ Strategy of Seller B } \\
\hline & & $\mathrm{DS}_{\mathrm{B}}$ & $\mathrm{IP}_{\mathrm{B}}$ & $\mathrm{SD}_{\mathrm{B}}$ & $E P_{B}$ \\
\hline \multirow{4}{*}{ 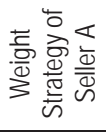 } & $\mathrm{DS}_{\mathrm{A}}$ & 0.085 & 0.096 & 0.123 & 0.091 \\
\hline & $\mathrm{IP}_{\mathrm{A}}$ & 0.246 & 0.258 & 0.114 & 0.265 \\
\hline & $\mathrm{SD}_{\mathrm{A}}$ & 0.100 & 0.118 & 0.135 & 0.173 \\
\hline & $E P_{A}$ & 0.569 & 0.528 & 0.629 & 0.471 \\
\hline & & $\mathrm{Cl}=0,06$ & $\mathrm{Cl}=0,00216$ & $\mathrm{Cl}=0,02$ & $\mathrm{Cl}=0,05$ \\
\hline
\end{tabular}

Source: Primary Data, processed, 2013

Table 4 shows some conditions:

a. In strategy of reducing the stock or the quantity of goods $\left(D_{B}\right)$ of seller $B$, it is shown that seller $A$ chooses to monitor price development in response to seller B's actions in reducing goods stock.

b. In B's strategy of increasing the price above the market or competitor $\left(\mathrm{IP}_{\mathrm{B}}\right)$ prices, seller A chooses strategy of keeping to monitoring the price development of goods

c. In strategy of shortening the distribution channels $\left(S_{B}\right)$ made by $B$, seller $A$ is still pursuing a strategy of monitoring the development of goods prices

d. In strategy of monitoring the price development $\left(E P_{B}\right)$ of seller $B$, seller A still does the action of monitoring the prices.

Payoff calculation technique made by seller $A$ is by multiplying the constant value of priority vector of seller A's strategy to his goal with the current value, that is, the weight of seller A's strategy with respect to alternative strategy of seller B. Hence, the Payoff of Seller A is as follows:

Table 5. Payoff of Seller $A$

\begin{tabular}{|c|c|c|c|c|}
\hline Strategy & $\mathrm{DS}_{\mathrm{B}}$ & $\mathrm{IP}_{\mathrm{B}}$ & $\mathrm{SD}_{\mathrm{B}}$ & $\mathrm{EP}_{\mathrm{B}}$ \\
\hline $\mathrm{DS}_{\mathrm{A}}$ & 0.007 & 0.008 & 0.010 & 0.008 \\
\hline $\mathrm{IP}_{\mathrm{A}}$ & 0.059 & 0.062 & 0.027 & 0.064 \\
\hline $\mathrm{SD}_{\mathrm{A}}$ & 0.008 & 0.010 & 0.011 & 0.015 \\
\hline $\mathrm{EP}_{\mathrm{A}}$ & 0.337 & 0.313 & 0.372 & 0.279 \\
\hline
\end{tabular}

Source: Primary Data, processed, 2013

Table 5 shows that toward any action taken by seller B in response to price increase, seller $A$ is still pursuing a strategy of monitoring price development; seller $\mathrm{A}$ is not affected by the action taken by seller $\mathrm{B}$.

Meanwhile, the calculation of priority strategies of subject of seller $B(A)$ is relation to the purpose of seller $B(A)$ and to each strategy of seller $A(B)$. The weight or priority vector of each strategy of seller $B$ is response to the goal of seller $A$.

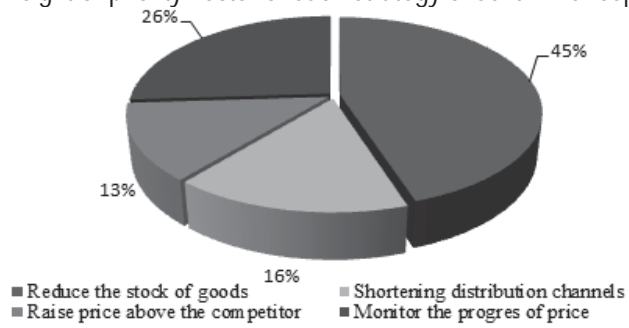

Figure 5. Priorities and Strategies of Subject of Seller B with respect to the goals

Description: Consistency Index of 0.06, Source: Primary data, processed, 2013 
In Figure 5, the priority strategies made by seller A are reducing the goods stock in weight of 0.448 and is followed by the strategy of monitoring price developments with a weight of 0.257 . Any strategy made by seller $B$ faces every strategy made by seller A. Thus, every action in strategy A, there is strategy B which is the most effective o respond to the A's action. The reaction of seller $B$ on each strategy made by subject of seller $A$ is as follows:

Table 6. Priority Strategies in relation to Strategy of Seller A

\begin{tabular}{|c|c|c|c|c|c|}
\hline & \multicolumn{4}{|c|}{ Strategy of Seller A } \\
\hline & & $\mathrm{DS}_{\mathrm{A}}$ & $\mathrm{IP}_{\mathrm{A}}$ & $\mathrm{SD}_{\mathrm{A}}$ & $E P_{A}$ \\
\hline \multirow{4}{*}{ 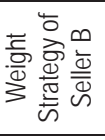 } & $\mathrm{DS}_{\mathrm{B}}$ & 0.292 & 0.421 & 0.375 & 0.343 \\
\hline & $\mathrm{IP}_{\mathrm{B}}$ & 0.196 & 0.164 & 0.197 & 0.185 \\
\hline & $\mathrm{SD}_{\mathrm{B}}$ & 0.326 & 0.210 & 0.213 & 0.276 \\
\hline & $E P_{B}$ & 0.186 & 0.205 & 0.216 & 0.196 \\
\hline & & $\mathrm{Cl}=0,07$ & $\mathrm{Cl}=0,07$ & $\mathrm{Cl}=0,04$ & $\mathrm{Cl}=0,07$ \\
\hline
\end{tabular}

Source: Primary Data, processed, 2013

Table 6 shows some conditions:

a. In strategies of reducing the stock or the amount of goods $\left(D S_{A}\right)$ from seller $A$, it is indicated that seller $B$ chooses to shorten the distribution channel in response to trader action in reducing stocks.

b. In the A's strategies of increasing the price above the market or competitor (IPA) prices, seller B chooses a strategy to reduce the stock or amount of goods.

c. In the strategy of shortening the distribution channel $\left(\mathrm{SD}_{\mathrm{A}}\right)$ made by $\mathrm{A}$, seller $\mathrm{B}$ chooses a strategy to reduce the stock or the amount of goods.

d. In the strategy of monitoring the price development of price (EPA) by seller A, seller B chooses strategy of reducing the stock or the amount of goods.

The calculation technique of Payoff of Seller B is by multiplying the constant value of the vector of priority strategies of seller $B$ toward his goal with current value, that is, the weight of seller $B$ in relation to the alternative strategies of seller A, so the payoff of seller B is as follows:

Table 7. Payoff of Seller B

\begin{tabular}{|c|c|c|c|c|}
\hline Strategy & $\mathrm{DS}_{\mathrm{A}}$ & $\mathrm{IP}_{\mathrm{A}}$ & $\mathrm{SD}_{\mathrm{A}}$ & $\mathrm{EP}_{\mathrm{A}}$ \\
\hline $\mathrm{DS}_{\mathrm{B}}$ & 0.131 & 0.189 & 0.168 & 0.154 \\
\hline $\mathrm{IP}_{\mathrm{B}}$ & 0.033 & 0.027 & 0.033 & 0.031 \\
\hline $\mathrm{SD}_{\mathrm{B}}$ & 0.042 & 0.027 & 0.027 & 0.035 \\
\hline $\mathrm{EP}_{\mathrm{B}}$ & 0.048 & 0.053 & 0.056 & 0.050 \\
\hline
\end{tabular}

Source: Primary Data, processed, 2013

Table 7 shows that any action taken by seller $A$ in response to price increase, seller $B$ still uses a strategy of reducing its stock or the amount of goods, seller B is not affected by the action taken by seller A. The payoff results of seller A in Table 5.5 and seller B in Table 5.7 made one in a payoff matrix, sellers A and B conflict will appear as follows:

Table 8. Payoff Matrix of Conflict between Sellers A and B

\begin{tabular}{|c|c|c|c|c|c|}
\hline \multirow{2}{*}{\multicolumn{2}{|c|}{ Payoff A Payoff B }} & \multicolumn{4}{|c|}{ Seller B } \\
\hline & & $\mathrm{DS}_{\mathrm{B}}$ & $\mathrm{IP}_{\mathrm{B}}$ & $\mathrm{SD}_{B}$ & $E P_{B}$ \\
\hline \multirow{4}{*}{ 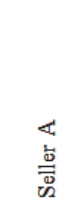 } & $\mathrm{DS}_{\mathrm{A}}$ & $0,007 \quad 0,131$ & $0,008 \quad 0,033$ & $0,010 \quad 0,042$ & $0,0088^{0,048}$ \\
\hline & $\mathrm{IP}_{\mathrm{A}}$ & $0,059 \underbrace{0,189}$ & $0,062 \quad 0,027$ & $0,027 \quad 0,027$ & \\
\hline & $\mathrm{SD}_{\mathrm{A}}$ & $\begin{array}{ll} & 0,168 \\
0,008\end{array}$ & $0,010 \quad 0,033$ & & \\
\hline & $\mathrm{EP}_{\mathrm{A}}$ & $0,337 \quad 0,154$ & $0,313 \quad 0,031$ & $0,372 \quad 0,035$ & 0,279 \\
\hline
\end{tabular}

Source: Primary Data, processed, 2013 
Whatever strategy of seller B is then responded by seller A by strategy of monitoring the price development. Similarly, seller $B$ will respond to any strategy made by seller $A$ by the strategy of reducing the stock of goods. Nash equilibrium occurs when seller $A(B)$ has no incentive to change the strategy, under a given strategy by seller $A(B)$. The outcome of Nash equilibrium is $\left[E P_{A} ; D_{B}\right]$ with payoff $[0.337 ; 0.154]$. These points can be achieved when there is no suspicion among sellers at the time or before the game is in progress, so that the commitment among sellers is necessary.

\subsection{Inter-Seller Behavioral Response to Change Prices: The Case of Falling Prices}

In the case of an increase in price, here is the model of interaction and strategy of seller if there is an increase in price.
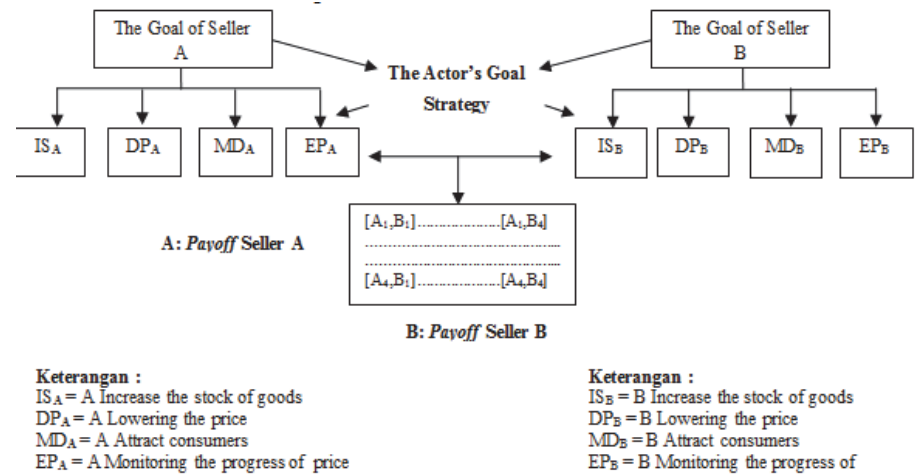

Keterangan :

$\mathrm{IS}_{\mathrm{B}}=\mathrm{B}$ Increase the stock of goods $\mathrm{DP}_{\mathrm{B}}=\mathrm{B}$ Lowering the price

Figure 6. Strategy and Response between subjects against Falling Prices

Figure 6 shows responses to each of sellers $A$ and $B$ toward the condition of the falling prices. The strategy made sellers $A$ and $B$ is increasing the number of merchandises, lowering the price below the market price or the main competitor, attracting consumers and monitoring the price developments of goods. Interaction between sellers A and B occurs at any good strategy made by $A$ or $B$. the payoff will further be calculated by both sellers $A$ and $B$ as a consequence of the interaction between the strategies of seller $B(A)$ vis a vis alternative strategy of $A(B)$. The consequence of payoff is calculated by AHP technique and arranged within the framework of game theory. Here are behavioral responses among sellers to price changes in one of the commodities in Jember Regency.

\subsubsection{Rice Commodity}

Here is the calculation of strategy priority of seller $A(B)$ with respect to the purpose of seller $A(B)$ and to each of the strategy of seller $B(A)$ for rice commodity. The weight or priority vectors of each strategy of seller $A$ is in relation to the purpose of $B$.

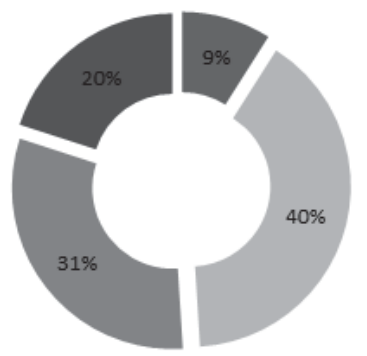

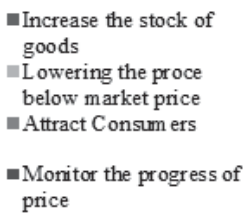

Figure 7. Priority and Strategy of Seller A with respect to the purrposes

Description: Consistency Index of 0.09, Source: Primary data, processed, 2013 
In Figure 7 , the strategy priority made by seller $\mathrm{A}$ is lowering the price below the market or the main competitor prices with a weight of 0.403 and followed a strategy to attract consumers with a weight of 0.314 .

Any strategy made by seller A faces any strategy of seller B. Thus, every action in strategy B, strategy A is the most effective strategy to respond to the actions of $B$. The reactions of seller A to any strategy made by seller $B$ are as follows:

Table 9. Strategy Priority of Seller A in relation to Strategy of Seller B

\begin{tabular}{|c|c|c|c|c|c|}
\hline & \multicolumn{4}{|c|}{ Strategy of Seller B } \\
\hline & & $I S_{B}$ & $D P_{B}$ & $\mathrm{MK}_{\mathrm{B}}$ & $E P_{B}$ \\
\hline \multirow{4}{*}{ 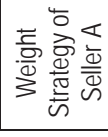 } & $I S_{A}$ & 0.050 & 0.065 & 0.054 & 0.059 \\
\hline & $\mathrm{DP}_{\mathrm{A}}$ & 0.414 & 0.402 & 0.504 & 0.464 \\
\hline & $\mathrm{MK}_{\mathrm{A}}$ & 0.251 & 0.245 & 0.252 & 0.250 \\
\hline & $E P_{A}$ & 0.284 & 0.288 & 0.190 & 0.227 \\
\hline & & $\mathrm{Cl}=0,09$ & $\mathrm{Cl}=0,09$ & $\mathrm{Cl}=0,02$ & $\mathrm{Cl}=0,06$ \\
\hline
\end{tabular}

Source: Primary data, processed, 2013

Table 9 shows some conditions, namely:

a. In the strategy of adding stocks or the number of goods $\left(I S_{B}\right)$ by seller $B$, it is shown that seller $A$ chooses to lower prices in response to the actions made by seller B in adding the goods stock.

b. In strategy of lowering the prices below the prices of market or competitor $\left(\mathrm{DP}_{\mathrm{B}}\right)$ of $\mathrm{B}$, seller $\mathrm{A}$ chooses strategy to lower the price below the market or competitor price.

c. In the strategy of attracting consumers $\left(\mathrm{MK}_{\mathrm{B}}\right)$ made by $\mathrm{B}$, seller $\mathrm{A}$ keeps doing the strategy of lowering the price of goods.

d. In monitoring the development of price strategy $\left(E P_{B}\right)$ of seller $B$, seller A still chooses the strategy of lowering the price below the market or competitor price.

The calculation technique of Payoff of Seller $A$ is by multiplying the constant value of strategy priority vector of seller $A$ to the goal with the current value of strategy weight of seller A with respect to alternative strategies of seller $B$, so the payoff of seller $\mathrm{A}$ is as follows:

Table 10. Payoff of Seller A

\begin{tabular}{|c|c|c|c|c|}
\hline Strategy & $\mathrm{IS}_{\mathrm{B}}$ & $\mathrm{DP}_{\mathrm{B}}$ & $\mathrm{MK}_{\mathrm{B}}$ & $\mathrm{EP}_{\mathrm{B}}$ \\
\hline $\mathrm{IS}_{\mathrm{A}}$ & 0.004 & 0.006 & 0.005 & 0.005 \\
\hline $\mathrm{DP}_{\mathrm{A}}$ & 0.167 & 0.162 & 0.203 & 0.187 \\
\hline $\mathrm{MK}_{\mathrm{A}}$ & 0.079 & 0.077 & 0.079 & 0.079 \\
\hline $\mathrm{EP}_{\mathrm{A}}$ & 0.056 & 0.056 & 0.037 & 0.044 \\
\hline
\end{tabular}

Source: Data Primer, diolah, 2013

Table 10 shows that any action taken by seller $B$ in response to the falling prices, seller A still uses the strategy of lowering the price below the market or competitor price; trader $A$ is not affected by the actions taken by $B$. Meanwhile, the calculation of strategy priority of seller $B(A)$ is in line with the purpose of seller $B(A)$ and in relation to each of the strategies of seller $A(B)$. The weight or priority vector of each strategy made by seller $B$ is in relation to the purpose of $A$.

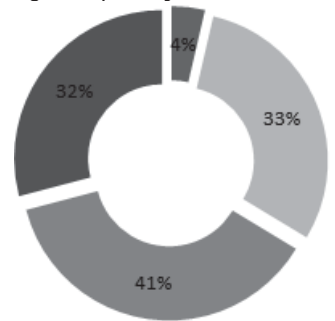

\footnotetext{
Increase the stock of goods

L L owering the proce below

market price

Attract Consum ers

Monitor the progress of price
}

Figure 8. Priorities and Strategies of Subject B with respect to the purposes

Description: Consistency Index of 0.05, Source: Primary data, processed, 2013 
In figure 8 , the priority strategy made by seller $A$ is attracting the consumers with a weight of 0.411 and followed strategy of lowering the prices with a weight of 0.333 . Any strategy made seller $B$ faces every strategy of seller $A$. Thus, in every action in strategy $A$, strategy $B$ is the most effective strategy to respond to the actions of $A$. The reactions of seller $A$ toward each strategy undertaken by seller $A$ are as follows:

Table 11. Strategy Priority by Seller B with respect to Strategy of Seller A

\begin{tabular}{|c|c|c|c|c|c|}
\hline & \multicolumn{4}{|c|}{ Strategy of Seller A } \\
\hline & & $\mathrm{IS}_{\mathrm{A}}$ & $\mathrm{DP}_{\mathrm{A}}$ & $\mathrm{MK}_{\mathrm{A}}$ & $E P_{A}$ \\
\hline \multirow{4}{*}{ 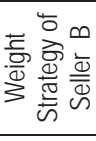 } & $I S_{B}$ & 0.045 & 0.044 & 0.045 & 0.049 \\
\hline & $\mathrm{DP}_{\mathrm{B}}$ & 0.269 & 0.283 & 0.307 & 0.290 \\
\hline & $\mathrm{MK}_{\mathrm{B}}$ & 0.453 & 0.323 & 0.435 & 0.488 \\
\hline & $E P_{B}$ & 0.232 & 0.350 & 0.214 & 0.173 \\
\hline & & $\mathrm{Cl}=0,04$ & $\mathrm{Cl}=0,01$ & $\mathrm{Cl}=0,04$ & $\mathrm{Cl}=0,09$ \\
\hline
\end{tabular}

Source: Primary data, processed, 2013

Table 11 shows some conditions:

a. In the strategy of adding stocks or the number of goods $\left(I S_{A}\right)$ made by seller $A$, it is shown that seller $A$ chooses to attract consumers in response to seller A's actions in adding goods stock.

b. In the strategy of lowering the price below the prices of market or competitor (DPA) made by $A$, seller $B$ chooses the strategy to monitor price development.

c. In the strategy of attracting consumers $\left(\mathrm{MK}_{\mathrm{A}}\right)$ made by $\mathrm{A}$, seller $\mathrm{B}$ also chooses a strategy to attract consumers.

d. In monitoring the development of price strategies $\left(E P_{A}\right)$ made by seller $A$, seller $B$ choses the strategy of attracting consumers.

The payoff calculation technique of seller $B$ is by multiplying constant value of the strategy priority vector of seller $B$ with current value i.e. weighted strategy of seller B with respect to the alternative strategy of seller A, so the payoff of seller $B$ is as follows:

Table 12. Payoff of Seller B

\begin{tabular}{|c|c|c|c|c|}
\hline Strategi & $\mathrm{IS}_{\mathrm{A}}$ & $\mathrm{DP}_{\mathrm{A}}$ & $\mathrm{MK}_{\mathrm{A}}$ & $\mathrm{EP}_{\mathrm{A}}$ \\
\hline $\mathrm{IS}_{\mathrm{B}}$ & 0.002 & 0.002 & 0.002 & 0.002 \\
\hline $\mathrm{DP}_{\mathrm{B}}$ & 0.090 & 0.094 & 0.102 & 0.097 \\
\hline $\mathrm{MK}_{\mathrm{B}}$ & 0.186 & 0.133 & 0.179 & 0.201 \\
\hline $\mathrm{EP}_{\mathrm{B}}$ & 0.050 & 0.075 & 0.046 & 0.037 \\
\hline
\end{tabular}

Source: Primary data, processed, 2013

Table 12 shows that any action taken by seller A in response to falling prices, seller B still applies the strategy of attracting consumers; seller B is not affected by the action taken by seller $A$. the payoff of seller A in Table 10 and payoff of seller B in table 12 is made into one payoff matrix of sellers A and B conflict, which will be seen in Table 13 as follows:

Table 13. Payoff Matrix of Sellers A and B Conflict

\begin{tabular}{|c|c|c|c|c|c|}
\hline \multirow{2}{*}{\multicolumn{2}{|c|}{${ }_{\text {Payoff A }}^{\text {Payoff B }}$}} & \multicolumn{4}{|c|}{ Seller B } \\
\hline & & $\mathrm{IS}_{\mathrm{B}}$ & $\mathrm{DP}_{\mathrm{B}}$ & $\mathrm{MK}_{\mathrm{B}}$ & $\mathrm{EP}_{\mathrm{B}}$ \\
\hline \multirow{4}{*}{ 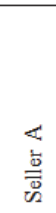 } & $\mathrm{IS}_{\mathrm{A}}$ & $0,004 \quad 0,002$ & $0,006 \quad 0,090$ & $0,005 \quad 0,186$ & $0,0055^{0,050}$ \\
\hline & $\mathrm{DP}_{\mathrm{A}}$ & $0,167 \quad 0,002$ & $0,162{ }^{0,094}$ & $0,203 \quad 0,133$ & 0,187 \\
\hline & $\mathrm{MK}_{\mathrm{A}}$ & 0,002 & $0,077 \quad 0,102$ & $\begin{array}{ll}0,079 & 0,179 \\
\end{array}$ & 0,079 \\
\hline & $\mathrm{EP}_{\mathrm{A}}$ & $0,056 \quad 0,002$ & $0,056 \quad 0,097$ & $\begin{array}{lll}0,037 & 0,201 \\
\end{array}$ & 0,044 \\
\hline
\end{tabular}

Source: Primary data, processed, 2013 
Whatever strategy made by seller B is responded by seller A by strategy of lowering prices below market or competitor price. Conversely, any strategy made by seller A, seller B will respond by strategy of attracting consumers through promotion. As long as the dominant strategy is the best response, then the partner strategy is Nash Equilibrium condition. Nash equilibrium occurs when seller $A(B)$ has no incentive to change strategy, under a given strategy made by seller $A$ (B). The outcomes of Nash equilibrium is $\left[\mathrm{DP}_{A} ; \mathrm{MK}_{B}\right]$ with payoff $]$ ].203; 0.133[. Both parties insist on a dominant strategy and trapped in situation $\mathrm{DP}_{\mathrm{A}}-\mathrm{MK}_{\mathrm{B}}$, that is, lowering the price by $\mathrm{A}$ and attracting customers by $\mathrm{B}$. In the case of rice commodity, the focal point that can happen is $\left[\mathrm{MK}_{\mathrm{A}} ; \mathrm{DP}_{\mathrm{B}}\right]$, that is, attracting consumers by seller $A$ and lowering the price below the market or competitor price by seller $\mathrm{B}$.

\section{Conclusions}

Price stability becomes an important prerequisite that is based on the consideration that shock on price movement can seriously give either economic or non-economic impacts. Therefore, it is very important to consider the sources or determinants of price formation in terms of demand and supply in a policy framework. The results of experiments and analysis of the determinants of price formation in Jember Regency to sellers as the subjects resulted some conclusions. The most influential determinant in the rise of prices seen from the sellers' preference is the purchase price at the level of the distributor/dealer. Price changes can be affected by the increase in fuel and crop failure that leads to the lowering volume of goods stock at the distributor level. Meanwhile, the sellers' preferences of factors that affect the decline in prices of goods is more dominantly affected by the decline in prices of goods and the supply of goods.

The results of analysis of subject preference toward the risks are the seller' asymmetric response. Sellers as subjects tend to choose the option that gives certainty, although it is harmful. This illustrates that the anticipation of sellers toward the risks is not symmetric. Asymmetric response to risk is a reflection of what is expected by the subjects in facing the uncertainty of a prospect.

The results of analysis of action and reaction between sellers to the conditions of the price change showed the dominant strategy for the case of the increase or decrease in the price of one of the main commodities. As long as the dominant strategy is the best response, then the partner strategy is Nash Equilibrium condition. Nash equilibrium occurs when seller $A(B)$ has no incentive to change strategy, under given strategy of seller $A(B)$. The dominant strategy or the prisoner's dilemma faced is vulnerable in the actions of mutual provocation, price wars and trade war.

\section{Recommendation for Further Researches}

1. This research mainly focuses on the behaviour analysis of group of traders in the market for retail level and has not yet involved the producers and big merchants as the participants in making economic decision.

2. This study has not yet comprehensively observed the trading chain from top to bottom, which is from the main manufacturer, main trader to consumers as well as the decision maker; which are Government and the stake holders.

3. Commodities sold for sampling are still limited to particular staple commodities.

Thus, it is expected that further research would involve great numbers of all market players and decision makers as well as include various range of commodities contributing to inflation. Consequently, related research would be able to serve as references for decision makers to maintain price stability in the regional or national level.

\section{References}

Andersson, Malin, Klaus Masuch and Marc Schiffbauer. (2009). Determinants of Inflation and Price Level Differentials Across The Euro Area Countries. Working Paper Series. No.1129. December.

Bank Indonesia. (2013). Maintaining Stability, Advancing Structural Reform For Sustainable Economic Growth. Report on Indonesia, ISSN 0522-2572.

Bernanke, B. S., \& Mishkin, F. S. (1997). Inflation Targeting : A New Framework For Monetary Policy?. National Berau of Economic Research Working Paper, 5893.

Capistr'an, C., \& Timmermann, A. (2009). Disagreement and biases in inflation expectations. Journal of Money, Credit and Banking, 41, $365-396$.

Cornille, D., \& Dossche, M. (2006). The patterns and determinants of price setting in the Belgian Industry. Working Paper Reserch

Gerdesmeier, D., Reimers, H.-E., \& Roffia, B. (2009). Asset Price Misalignment and The Role of Money and Credit. ECB Working Paper, 1068.

Gordon, R. J. (2009). The History of the Philips Curve : Consessus and Bifurcation. NBER Working Paper. 
Gyebi, Francis and Godfried K. Boafo. (2013). Macroeconomic Determinants of Inflation in Ghana From 1990-2009. International Journal of Business and Social Research (IJBSR). Vol 3 No 6. June.

Harbaugh, W. T., Krause, K., \& Vesterlund, L. (2007). Learning to Bargain. Journal of Economic Psychology, 28, 127-142.

Huang, M. H., Hahn, D. E., \& Jones, E. (2004). Determinan of Price Elasticities for Store Brands and National Brands of Cheese. Paper for presentation at the American Agiculture Economics Association Annual Meeting

Hutabarat, Akhis R.. 2005. Determinan Inflasi Indonesia. Occasional Paper No OP/06/2005. Bank Indonesia

Kahneman, D., \& Tversky, A. (1979). The Framing of Decisions and the Psychology of Choice. Science, New Series (211), $4481,453-$ 458.

Laryea, S. A., \& Sumaila, U. R. (2001). Determinants of inflation in Tanzania. CMI Working Papers, (12).

Levin, J. (2006). Choice Under Uncertainty. [Online] Available: http://web.stanford.edu/ jdlevin/Econ \%20202/Uncertainty.pdf

Lim, Cheng Hoon and Laura Papi. (1997). An Econometric Analysis of the Determinants of Inflation in Turkey. IMF Working Paper. WP/97/170. December.

Lim, Yen Chee and Siok Kun Sek. (2015). An Examination on the Determinants of Inflation. Journal of Economics, Business and Management. Vol 3. No 7. July.

Lyziak, T. (2014). Inflation expecations in Poland, 2001-2013 Measurement and macroeconomic testing. NBP Working Paper, No. 178.

Madeira, C., \& Zafar, B. (2012). Heterogeneous Inflation Expectations and learning. Federal Reseve Bank of New York, (536).

Makinen, G. E., \& Labonte, M. (2008). Inflation: Causes, Cost, and Current Status. CRS Report for Congress.

Markowitz, P. (1952). Portofolio Selection. The Journal of Finance, (7), 1, 77-91.

Mlambo, L. (2012). Adaptive and Rational Expectations Hypotheses : Reviewing The Critiques. Journal of Economics behaviour, (2), 315.

Narahari, Y. (2012). Game Theory. [Online] Available: http://www.isical.ac.in/ scc/SNAW_Lecture_Material/Y_Narahari/ISI-GT-Intro.pdf

Pradiptyo, Rimawan, Banoon Sasmitasiwi dan Erwin Andreas Tumengkol. (2011). Respon Pengusaha Terhadap Informasi Pembentukan Inflasi Kota Yogyakarta. Laporan Penelitian. Penelitian dan Pelatihan Ekonomika dan Bisnis (P2EB) Fakultas Ekonomika dan Bisnis Universitas Gadjah Mada. Yogyakarta

Prijambodo, B. (2006). Optimalisasi Koordinasi Kebijakan Untuk Mencapai Efektifitas Inflation Targeting. [Online] Available: https://academia.edu/15358991.

Rabin, M. (1999). Risk Aversion and Expected - Utility Theory : A Calibration Theorem. [Online] Available: http://elsa.berkeley.edu/ rabin/index.html

Ravenna, F., \& Seppala, J. (2007). Monetary policy, expected inflation and inflation risk premia. Bank of Finland Research Discussion Papers, (18).

Saaty, T. L. (2008). Decision making with the analytic hierarchy process. Int. J. Services Sciences, (1), 83 - 98.

Tesfatsion, L. (2014). Elements of Dynamic Economic Modeling : Presentation and Analysis. ISU Economics Working Paper, (14001), 128.

Turocy, T. L., \& Stengel, B. V. (2001). Game Theory. CDAM Research Report LSE-CDAM, 2001, 09.

Walsh, C. E. (2002). Teaching Inflation Targeting: An Analysis for Intermediate Macro. The Journal of Economic Education, 33(4), 333346.

Westcott P. C., and Hoffman, L. A. (1999). Price Determination for Corn and Wheat: The Role of Market Factors and Government Programs. Technical Bulletin, (1878).

White, W. R. (2006). Is price stability enough ?. BIS Working Paper, (205), 1-22.

Woodford, M. (2013). Forward Guidance by Inflation- Targeting Central Banks. Paper on Conference Sveriges Riskbank. 